\title{
Ultrastructural analysis of the dorsal body gland of the terrestrial snail Megalobulimus abbreviatus (Becquaert, 1948)
}

\author{
Moraes, GD. ${ }^{\mathrm{a}, \mathrm{d}}$, Achaval, M. ${ }^{\mathrm{b}, \mathrm{c}}$, Dal Piva, MM. ${ }^{\mathrm{a}}$, Faccioni-Heuser, MC. ${ }^{\mathrm{b}, \mathrm{c}}$, \\ Wassermann, GF. ${ }^{\mathrm{d}}$ and Zancan, DM. ${ }^{\mathrm{a}, \mathrm{c} *}$

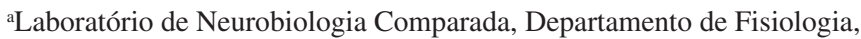 \\ Instituto de Ciências Básicas da Saúde, Universidade Federal do Rio Grande do Sul - UFRGS, \\ CEP 90050-170, Porto Alegre, RS, Brazil \\ 'Laboratório de Histofisiologia Comparada, Departamento de Ciências Morfológicas, \\ Instituto de Ciências Básicas da Saúde, Universidade Federal do Rio Grande do Sul - UFRGS, \\ CEP 90050-170, Porto Alegre, RS, Brazil \\ ${ }^{\mathrm{c} C e n t r o ~ d e ~ M i c r o s c o p i a ~ E l e t r o ̂ n i c a, ~ U n i v e r s i d a d e ~ F e d e r a l ~ d o ~ R i o ~ G r a n d e ~ d o ~ S u l ~-~ U F R G S, ~}$ \\ Av. Bento Gonçalves, 9500, CEP 91540-000, Porto Alegre, RS, Brazil \\ ¿Departamento de Fisiologia, Instituto de Ciências Básicas da Saúde, \\ Universidade Federal do Rio Grande do Sul - UFRGS, \\ CEP 90050-170, Porto Alegre, RS, Brazil \\ *e-mail: zancan@ufrgs.br \\ Received July 31, 2008 - Accepted October 7, 2008 - Distributed May 31, 2010
}

(With 5 figures)

\begin{abstract}
The ultrastructure of the reproductive gland, dorsal body (DB), of Megalobulimus abbreviatus was analysed. Electron microscope immunohistochemistry was used to detect FMRFamide-like peptides in the nerve endings within this gland. Nerve backfilling was used in an attempt to identify the neurons involved in this innervation. In M.abbreviatus, the DB has a uniform appearance throughout their supraesophageal and subesophageal portions. Dorsal body cells have several features in common with steroid-secreting gland cells, such as the presence of many lipid droplets, numerous mitochondria with tubular cristae and a developed smooth endoplasmic reticulum cisternae. Throughout the DB in M. abbreviatus numerous axonal endings were seen to be in contact with the DB cells exhibiting a synapticlike structure. The axon terminals contained numerous electron-dense and scanty electron-lucid vesicles. In addition, the DB nerve endings exhibited FMRFamide immunoreactive vesicles. Injection of neural tracer into the DB yielded retrograde labelling of neurons in the metacerebrum lobe of the cerebral ganglia and in the parietal ganglia of the subesophageal ganglia complex. The possibility that some of these retrograde-labelled neurons might be FMRFamidelike neurons that may represent a neural control to the DB in M. abbreviatus is discussed.
\end{abstract}

Keywords: mollusc, endocrine gland, FMRFamide, cerebral ganglia, reproductive control.

\section{Análise ultraestrutural da glândula corpo dorsal do caracol terrestre Megalobulimus abbreviatus (Becquaert, 1948)}

\section{Resumo}

Foi analisada a ultraestrutura da glândula reprodutiva corpo dorsal (CD) de Megalobulimus abbreviatus. Imunoistoquímica para microscopia eletrônica foi utilizada para detectar peptídeos relacionados ao tetrapeptídeo FMRFamida nas terminações axonais existentes nessa glândula. Foi utilizada marcação neuronal retrógada com o intuito de localizar os neurônios envolvidos nesta inervação. O CD de M. abbreviatus possui um aspecto uniforme em toda sua extensão, tanto na porção supraesofágica como subesofágica. As células do CD possuem várias características de glândulas esteroidogênicas, tais como a presença de inúmeras gotículas lipídicas, numerosas mitocôndrias com cristas tubulares e cisternas bem desenvolvidas de retículo endoplasmático liso. Por toda a extensão do CD de M. abbreviatus foram encontradas numerosas terminações axonais fazendo contatos estruturalmente semelhantes a sinapses com as células do $\mathrm{CD}$. As terminações axonais continham grande número de vesículas eletrodensas e esparsas vesículas eletrolúcidas. As terminações axonais no $\mathrm{CD}$ apresentavam vesículas com conteúdo imunorreativo à FMRFamida. A injeção de traçador neural no $\mathrm{CD}$ resultou em marcação retrógrada de neurônios no metacérebro dos gânglios cerebrais e nos gânglios parietais do complexo ganglionar subesofágico de M. abbreviatus. É discutida a possibilidade de que estes neurônios identificados por marcação retrógrada possam representar a via de controle neural do CD de M. abbreviatus, cujo mediador químico seria um neuropeptídeo relacionado à FMRFamida.

Palavras-chave: molusco, glândula endócrina, FMRFamida, gânglio cerebral, controle reprodutivo. 


\section{Introduction}

The dorsal body (DB) is an endocrine organ located above the cerebral ganglia in all pulmonate gastropod molluscs. The DB synthesises a hormone that influences vitellogenesis, and the differentiation and growth of the accessory sex glands of the feminine portion of the genital system (Joosse and Geraerts, 1983; Flari and Edwards, 2003).

The DB can take the form of a pair (or two pairs in some species) of distinct compact organs attached to the cerebral ganglia, as occurs in basommatophoran snails (Luchtel et al., 1997), or consists of scattered cell clusters in the connective tissue that partially surrounds the cerebral ganglia, as in stylommatophoran snails (Kuhlmann, 1966; Wijdenes and Runham, 1976). However, in some stylommatophoran species the presence of DB cells in the connective tissue surrounding the subesophageal ganglia has also been identified (Succinea putris, Cook, 1966; Limax maximus, van Minnen and Sokolove, 1984; Helix aspersa, Marchand and Dubois, 1986).

The DB of Megalobulimus abbreviatus displays a few peculiar features. It is a single organ, as in other terrestrial snails, but has a compact aspect as in aquatic snails, and is the largest among the members of the Stylommatophora (Kuhlmann, 1966). The M.abbreviatus DB extends from the posterodorsal region of the cerebral ganglia to the dorsal limit of the pleural and parietal ganglia located in the subesophageal ganglionic complex, along the course of the cerebral pleural connectives. Thus, it constitutes a single structure, most of which lies within the supraesophageal portion of the nerve ring together with two symmetrical projections that extend to the subesophageal portion (Zancan and Achaval, 1995).

The chemical composition of the DB hormone remains controversial, though the arguments for it being composed of steroids (Krusch et al., 1979; Griffond and Vincent, 1985; Nolte et al., 1986; Miksys and Saleuddin, 1988, Mukai et al., 2001) are stronger than those that suggest it is peptidergic in nature (Ebberink et al., 1983; Jong-Brink et al., 1986). The DB cells do not significantly express a peptidergic gene, but, on the other hand, encode an abundant amount of cytochrome P450 protein analogue, which would suggest a steroid synthesis (Teunissen et al., 1992), or, more specifically, synthesis of an ecdysteroid (Krusch et al., 1979; Nolte et al., 1986), using a different biosynthetic pathway from that of arthropods (Garcia et al., 1995). In Helix aspersa, the DB synthetic activity is controlled in an inhibitory manner by cerebral ganglion neurons, which produce a growth hormone (Wijdenes et al., 1983, 1987; Vincent et al., 1984). On the other hand, it has been suggested that some neuropeptides exert a regulatory role, such as the molluscan insulin-related peptide (MIP) in Lymnaea stagnalis (Geraerts et al., 1991) and Phe-Met-Phe-NH $\mathrm{NH}_{2}$ (FMRFamide) or Met-enkephalin in H. aspersa (Marchand et al. 1991; Griffond and Mounzih, 1990).
A previous study of the DB of Megalobulimus abbreviatus revealed seasonal variations with a higher synthetic activity at the beginning of spring (Zancan and Achaval, 1995). This period coincides with the initiation of the reproductive phase of these animals (Horn et al., 2005). These typical characteristics of $M$. abbreviatus $\mathrm{DB}$, such as its large size, the fact that it is a single organ with a dense aspect, its close contact with three different ganglia of the central nervous system, encourage further investigation of the ultrastructural aspects of this gland and its relationship with neural structures. In order to investigate the existence of a neuropeptidergic innervation of the M. abbreviatus DB cells, electron microscopic immunohistochemistry was used to detect the FMRFamide-like substance. To identify the neurons that could be involved in this innervation, a solution of cobalt chloride was injected into the DB gland.

\section{Material and Methods}

The pulmonate snail utilised was Megalobulimus abbreviatus Becquaert 1948 (MNRJ 13283), previously cited incorrectly as Megalobulimus oblongus or Strophocheilus oblongus. A previous work about the general anatomy of Megalobulimus abbreviatus has already been published (Thomé et al., 1994). Adult specimens were collected in the county of Charqueadas in the State of Rio Grande do Sul, Brazil, and maintained in a screened terrarium at $23-27{ }^{\circ} \mathrm{C}$ under a 12 hours light/ dark cycle, and with food and water ad libitum. In order to minimise seasonal influences, most of the animals were maintained in these conditions for at least 30 days prior to their use in the experiments. Nevertheless, in order to identify the seasonal variation of the cellular ultrastructural morphology of the DB, six animals (shell lengths of 7.0-8.0 cm and weighing 50 to $84 \mathrm{~g}$ ) were immediately used after the collection and different regions of the DB were analysed (Figure 1).

The DB glands from six snails, maintained in laboratory controlled conditions, were processed for transmission electron microscopy (TEM) immunohistochemistry. The cerebral (CG) and subesophageal ganglia (SubG), with the adjacent DB, obtained from anaesthetised animals (immersion in a saturated menthol solution for 30 minutes), were dissected out and fixed in a solution of $4 \%$ paraformaldehyde and $0.25 \%$ glutaraldehyde in $0.1 \mathrm{M}$ phosphate buffer (PB) $\mathrm{pH} 7.4$, at room temperature for 4 hours. After fixation, the samples were cryoprotected in a $30 \%$ sucrose solution in $0.1 \mathrm{M} \mathrm{PB}$ at $4{ }^{\circ} \mathrm{C}$. The material was frozen in liquid nitrogen, thawed in $\mathrm{PB}$ and then horizontal sections $(50 \mu \mathrm{m})$ were obtained using a vibratome (Leica, Germany). The free-floating sections were submitted to the peroxidase-antiperoxidase (PAP) procedure. Briefly, 1) the sections were pretreated in $3 \% \mathrm{H}_{2} \mathrm{O}_{2}$ in $10 \%$ methanol for 30 minutes; 2) nonimmune goat serum 1:50 in PBS for 30 minutes; 3) rabbit anti-FMRFamide (polyclonal antibody, Chemicon, USA) diluted (1:900) in phosphate buffer saline (PBS) 
for 48 hours at $4{ }^{\circ} \mathrm{C}$; 4) anti-rabbit IgG serum (Sigma, USA) diluted 1:50 in PBS, for 1.5 hour at room temperature; and 5) PAP complex (Sigma, USA) diluted 1:500 in PBS for 1.5 hours at room temperature. The immunoreaction was developed with $0.06 \%$ 3,3'-diaminobenzidine tetrahydrochloride (Sigma, USA) in PBS containing $0.01 \% \mathrm{H}_{2} \mathrm{O}_{2}$ for 10 minutes. The specificity of the immunoreaction was verified by omitting the first antibody in the incubation medium. Under this experimental condition immunoreactivity did not occur. The sections were carefully washed in PBS and then processed for TEM. They were postfixed in $1 \% \mathrm{OsO}_{4}$ (Sigma, USA) diluted in $\mathrm{PB}$ for 1 hour, rinsed in $\mathrm{PB}$, dehydrated in ascending graded series of ethanol and propylene oxide (Electron Microscopy Sciences, USA) and embedded in araldite (Durkupan, ACM Fluka, Switzerland) and maintained in a vacuum for 24 hours. Afterwards, they were mounted onto slides covered with acetate coverslips, and polymer-
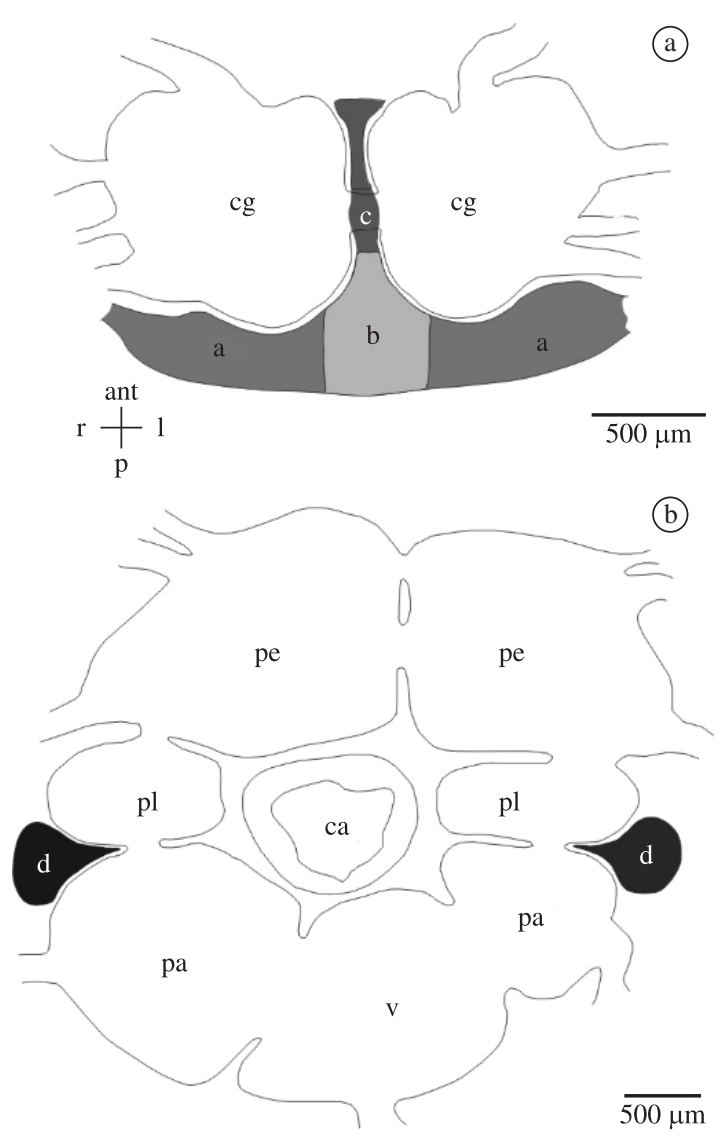

Figure 1. Schematic representation of horizontal sections of the central nervous system of $M$. abbreviatus showing the different regions of the dorsal body. a) Cerebral ganglia (cg) and dorsal body regions (a, b, c). b) Subesophageal ganglia and the other dorsal body region (d), located between parietal (pa) and pleural (pl) ganglia. Cephalic artery (ca), pedal ganglion (pe); visceral ganglion; (v). ant, anterior; 1, left; r, right; $\mathrm{p}$, posterior. ized for 48 hours at $60{ }^{\circ} \mathrm{C}$. After this, the DB areas were selected, as shown in Figure 1 and transferred to araldite blocks. Ultrathin sections $(70 \mathrm{~nm})$ were obtained using an ultramicrotome MT 6000-XL, RMC (Tucson, USA), mounted on copper grids and stained with $2 \%$ uranyl acetate and $1 \%$ lead citrate. The material was examined using a transmission electron microscope (JEM 1200 EX II, Japan; Electron Microscopic Centre, UFRGS). For a qualitative analysis of the seasonal variations, other DB glands from six snails were processed only for TEM, as described above.

Cobalt chloride (Sigma) $0.1 \mathrm{M}$ with $0.1 \%$ bovine albumin (Sigma) was used for nerve backfilling in the DB extracellular area. In order to perform the neural tracing in vitro, the CNS was removed from anesthetised snails. In contrast to helicidae species, in M. abbreviatus, no nerve fascicles were found extending from the supra or subesophageal ganglia to the DB (Zancan and Achaval, 1995). Therefore, the neural tracer was injected (0.1 to $0.3 \mu \mathrm{L}$ ) with a Hamilton syringe (USA) into a small wound made in the medial portion of the DB, posteriorly located to the cerebral ganglia. A similar incision was made in the subesophageal portion of the DB. The wound regions were covered with a layer of vaseline grease and the preparation was kept in a moist chamber overnight at $4{ }^{\circ} \mathrm{C}$ in order for the cobalt ions to diffuse. After this, cobalt was precipitated as cobalt sulphide by addition of $0.3 \%$ ammonium sulfide (Merck, Germany) for 20 minutes. Afterwards, the material was carefully washed and fixed in Carnoy solution for 1 hour. Then, the ganglia-DB complex was hydrated and cryoprotected in $30 \%$ sucrose solution in $0.1 \mathrm{M} \mathrm{PB}$ at $4{ }^{\circ} \mathrm{C}$. The tissue was sectioned in a cryostat (Leitz 1720 Digital; $100 \mu \mathrm{m})$ and mounted onto gelatinised slides. The material was submitted to silver intensification according to the Davis method (Davis, 1982), using a freshly prepared 8:1:1 mixture of solutions A (1\% Triton X-100; sodium acetate; glacial acetic acid; silver nitrate): B (5\% sodium tungstate): $\mathrm{C}$ ( $0.25 \%$ ascorbic acid) for 10 minutes. The sections were washed in distilled water, dehydrated in ascending graded series of ethanol, cleared with methyl salicylate, and covered using balsam and coverslips.

\section{Results}

The appearance of the DB cells was uniform throughout the different portions of the DB. These small cells (12-26 $\mu \mathrm{m}$ in diameter) were irregular in shape, thin with short cytoplasmic processes of variable length without any orientation. There was no cluster formation; instead the distribution was even throughout the organ and within the loose connective tissue and vessels. The DB cells fixed in summer had a shrunken aspect (Figure 2a), with an increased intercellular space occupied by thin collagen fibrils and smooth muscle cells. The polymorphic nuclei of the DB cells were centrally positioned with several indentations in the nuclear envelope and heterochromatin granules against this membrane and large nu- 
cleoli (Figure 2a, d). Sometimes these cells were seen to exhibit cilia (Figure 2c).

A number of features were seen to be constant in the cytoplasm of the DB cells. These included lipid droplets
(Figures 2a, e), round or oval mitochondria with variable distribution of their tubular cristae (Figure 2c), smooth endoplasmic reticula (SER) whose cisternae were frequently surrounding the lipid droplets, similarly second-
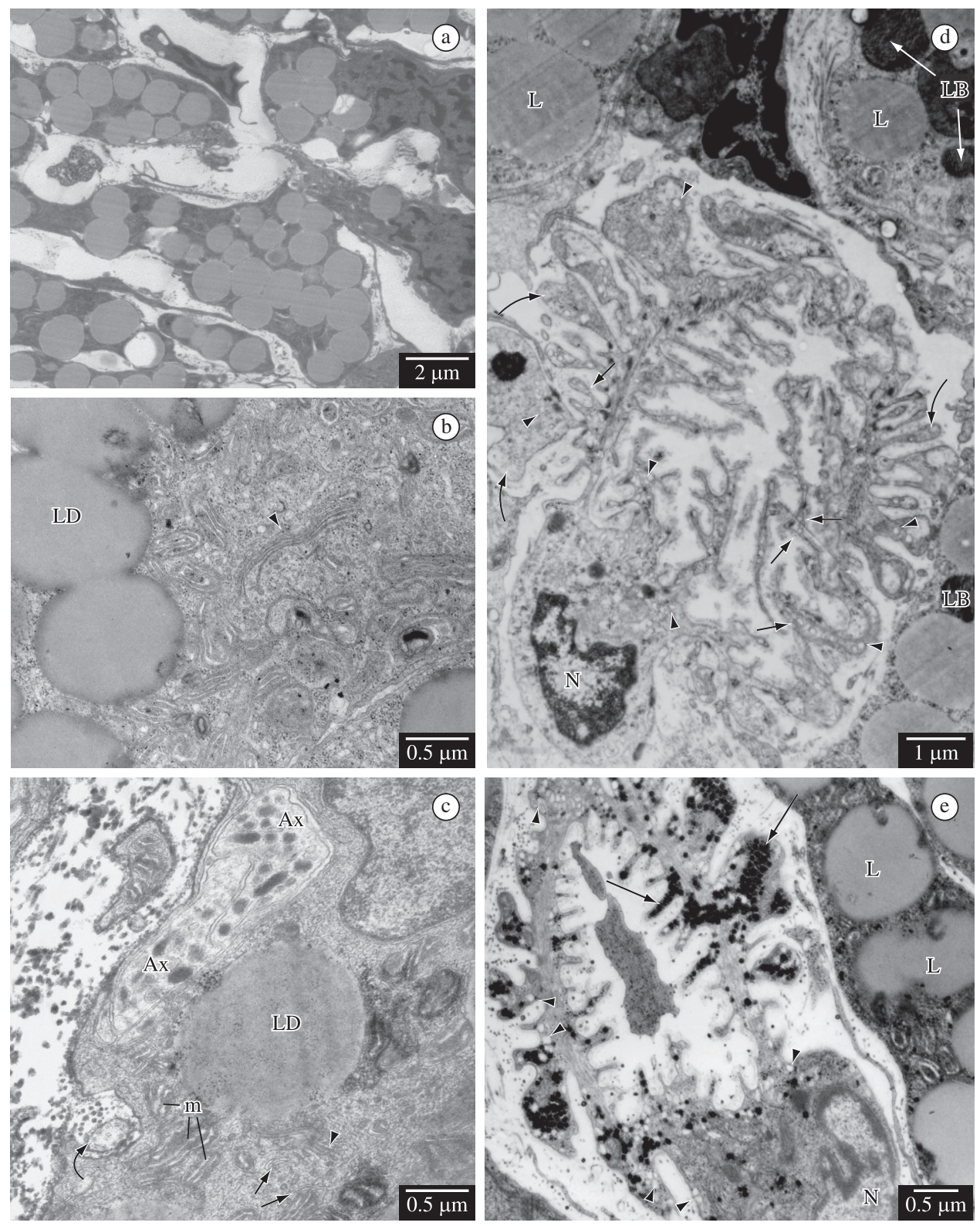

Figure 2. Dorsal body (DB) cells of the M. abbreviatus. a) DB fixed in summer (non-reproductive period) showing a shrunken process filled with lipid droplets and an increased intercellular connective space. b) DB fixed in spring (reproductive period) displaying a well-developed Golgi complex (arrowhead), lipid droplets (LD) surrounded by smooth endoplasmic reticula cisternae and mitochondria. c) Two axon terminals (Ax), surrounded by DB cellular processes, containing dense vesicles. Note in the DB cell, mitochondria (m), smooth endoplasmic reticula (arrow), Golgi complex (arrowhead), lipid droplet (LD). A cilium (curved arrow) can be seen adjacent to this DB cell. d) The DB capillary (fixed in summer) is constituted of endothelial cells displaying numerous and extensive folds (curved arrows) in luminal and adluminal regions. The endothelial cytoplasm shows small clear vesicles (arrowheads) and is surrounded by a complete basal lamina. Omega figures are identified (arrows) along the plasma membrane. e) The endothelial cytoplasm of this DB capillary (fixed in spring) presents numerous glycogen granules (arrows) and some small clear vesicles (arrowheads). L, lipid droplets in DB cells; N, endothelial cell nuclei. 
ary lysosomes were distributed close to the lipid droplets (Figure 2c), well-developed Golgi complex containing saccules with an electron-dense content, proving the high secretory activity of the DB cells (Figures 2b, c). Moreover, some moderate electron-dense secretory granules (30-60 nm in diameter) and scanty cisternae of the rough endoplasmic reticulum (RER) were observed.

In all the DB regions studied, numerous axon endings were in close contact with DB cells forming synaptic-like structures. A cleft without a basal lamina was interposed between the axon and DB cell membranes (Figures $3 \mathrm{c}, \mathrm{d}$ ). In the posteromedial region of the DB, dorsal to the cerebral commissure, pre-terminal axons and small nerve fascicles or thin nerves were more frequently detected (Figures $3 \mathrm{a}, \mathrm{b}$ ). The axon terminals contained rounded electron-dense, or moderate electrondense, membrane-bound vesicles $(60-130 \mathrm{~nm}$ in diameter) and some ellipsoidal vesicles (Figures $3 \mathrm{~b}, \mathrm{c}$ ). The common round electron dense vesicles were also found in the axons of the nerve fascicles. Usually, the DB cell processes surrounded the axonal terminals, showing intimate contact between them (Figures 2c, 3c, 3d).

The extracellular space displayed continuous capillaries. In summer, the luminal and adluminal plasma
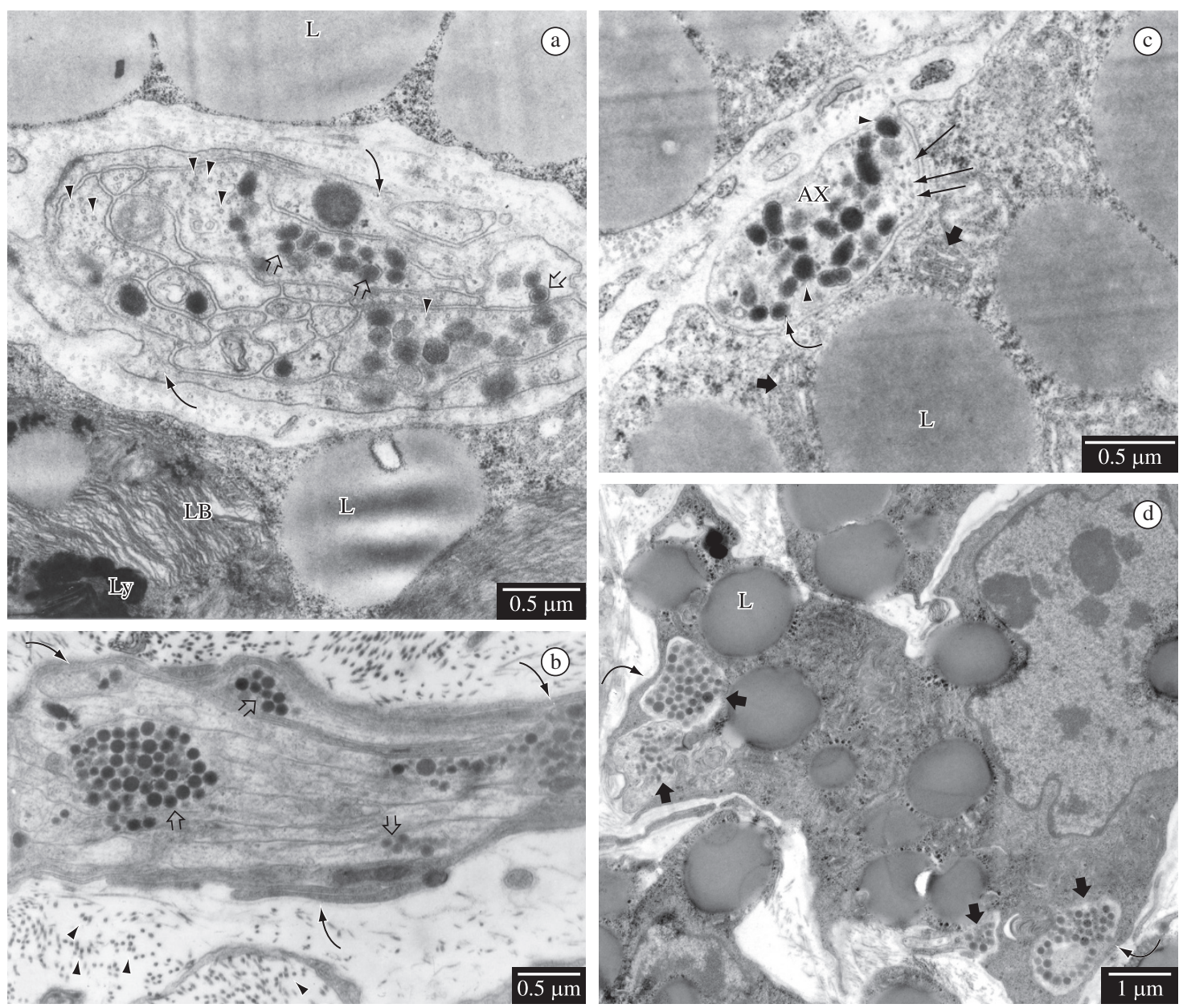

Figure 3. Innervation of the DB cells. a) Small nerve in the DB area (curved arrow), containing several axons exhibiting dense core vesicles (open arrow) and also cross-sections of neurotubules (arrowheads). This nerve is surrounded by loose connective tissue (with collagen fibrils), and which is, in turn, surrounded by DB cells. Lipid droplets (L), secondary lysosome (Ly), lamellar body (LB). b) Larger nerves (obliquely sectioned) can be found in the DB area near the dorsal portion of the CG commissure. This nerve is completely surrounded by glial processes (curved arrows). These axons showed clusters of electron-dense vesicles (open arrows), neurotubules and neurofilaments. c) Axon terminal forms a close contact (synapselike) with the DB cells. Electron-dense (arrowhead) and less electron-dense vesicles (curved arrow) and neurotubules (thin arrows) can be observed within the terminal. Note the cytoplasm of the DB cell with lipid droplets (L) and mitochondria (black arrow). d) DB cells with lipid droplets (L) and an indented nucleus with some nucleoli. The arrows indicate several axon terminals or pre-terminal processes in very close contact with one DB cell. Frequently the DB cells emit processes which surround the axon terminals (curved arrows). 


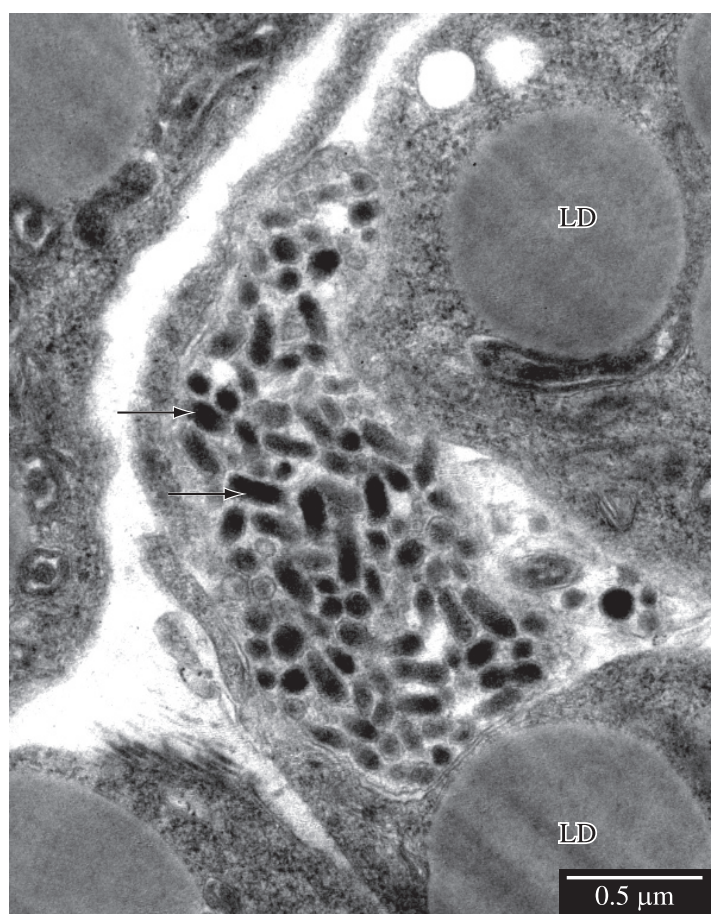

Figure 4. Immunoelectron micrograph of the dorsal body showing FMRFamide-ir vesicles in neurites (arrows) that is located in a depression of a DB cell and almost completely surrounded by cellular processes in intimate contact with this cell. LD, lipid droplets. membrane of the endothelial cells showed numerous folds and their cytoplasm contained mostly electron lucid transendothelial vesicles. Sometimes omega structures were detected in the plasma membrane (Figure 2d). In the reproductive period (spring time), the DB endothelial cells displayed numerous glycogen rosettes together with a reduced number of electron lucid transendothelial vesicles in the cytoplasm (Figure 2e). In both seasons, intermediate filaments were found (Figure 2e) and a basal lamina was seen to completely surround the endothelial cells.

As was observed in a previous study using light microscopy immunohistochemistry with antiserum against FMFRamide, the DB tissue showed an intense immunoreaction (Moriguchi-Jeckel, 2001). At the electron microscopic level, FMRFamide immunoreactivity (FMRF-IR) was found in the neurosecretory vesicles of these dorsal body nerve endings (Figure 4).

The CG and the subG were examined following retrograde axonal transport of cobalt chloride injected into the posterior medial portion of DB. With a low concentration of cobalt chloride utilised, it was possible to obtain successful retrograde labelling, without background or nonspecific staining. In the pleural lobe of the metacerebrum, close to the boundary with DB, a cluster of about 90 labelled neurons $(22-40 \mu \mathrm{m}$ in diameter) was found (Figure 5b). With this tracer it was also possible to label the axonal processes projecting from the cerebral commissure toward the metacerebrum neuropile. This labelled metacerebrum neuronal cluster extends from the
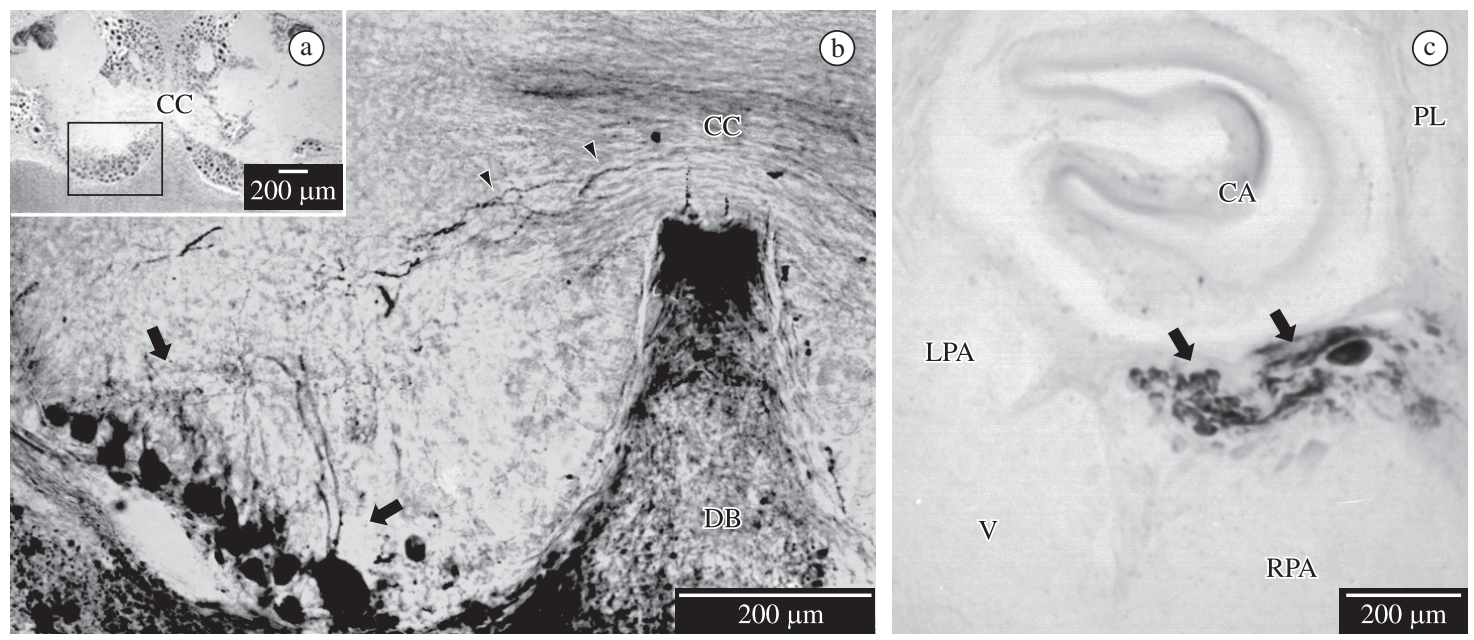

Figure 5. Horizontal sections of the cerebral ganglia ( $a$ and b) and the subesophageal ganglia (c). a) Cerebral ganglia at the cerebral commissure (CC) level to show neuronal region of the pleural lobe (inset), which appears labelled in B. b) A neuronal cluster (arrows) of metacerebrum (pleural lobe) exhibiting backfilling with cobalt applied to the dorsal body (DB) region posteriorly located to the cerebral ganglia. Some labelled axons (arrowhead) project to the cerebral commissure (CC) and to the DB area adjacent to this commissure. c) In the right parietal ganglion (RPA) neurons (arrows) were labelled by cobalt application to the DB region located between the pleural (PL) and right parietal ganglion. Cerebral artery (CA); left parietal ganglion (LPA); visceral ganglion (V). 
ganglionic dorsal surface toward the cerebral commissure (medial) level (about $500 \mu \mathrm{m}$ in length) and seems to be bilaterally symmetric. Other labelled neurons (30-38 $\mu \mathrm{m}$ in diameter) were found in the anterior portion of the right or left parietal ganglion (Figure 5c), depending on which side of the DB subesophageal portion received the tracer injection (portion "d" of the schematic representation in Figure 1). The number of labelled cell bodies was greater in the right parietal (up to 58 cells) than in the left parietal ganglion (17 cells, at most). Both neuronal clusters extend from the dorsal region toward the medial portion of these ganglia. No labelled neurons were found either in the other subesophageal ganglia or neural lobes of the CG.

\section{Discussion}

Despite the distinct anatomical aspect of the DB of Megalobulimus abbreviatus compared to the DB of the other studied pulmonate molluscs, the ultrastructural characteristics of the DB cells of M. abbreviatus are similar to those of other pulmonates. The DB cells have general features in common to steroid-secreting gland cells, such as the presence of a large number of mitochondria with longitudinal cristae, abundant lipid droplets and developed SER cisternae. These characteristics have also been described for Helix pomatia (Nolte et al., 1986), Helix aspersa (Wijdenes et al., 1983), Achatina fulica (Ohtake and Takeda, 1994), Theba pisana (Nolte, 1983), Arion rufus (Ezzughayyar and Wattez, 1989), and for the aquatic pulmonates Helisoma duryi (Saleuddin et al., 1989) and Siphonaria pectinata (Saleuddin et al., 1997). Indeed, it was demonstrated that the DB cells of H. pomatia and Lymnaea stagnalis have the capacity to synthesise ecdysteroids (Krusch et al., 1979; Nolte et al., 1986, Mukai and Saleuddin, 1992; Mukai et al., 2001), specifically ecdysone (Nolte et al., 1986). Considering the ecdysteroids are not exogenously derived in the pulmonates (Jong-Brink et al., 1989), this subclass must use a different biosynthetic pathway from that of arthropods (Garcia et al., 1995). There is also some indirect evidence to support the steroidogenic role of the DB. Physiological actions which have been attributed to the $\mathrm{DB}$, such as the synthesis and release of galactogen by the albumen gland in H. aspersa (Bride et al., 1991) and the sexual maturity of Biomphalaria glabrata (Schiff and Dosage, 1991) can be stimulated by administering 20-hydroxyecdysone.

The DB cells of Megalobulimus abbreviatus also present clear signs of a capacity for protein synthesis, such as the presence of a large nucleolus, RER cisternae, and a Golgi apparatus with electron-dense content. These characteristics have also been observed in the DB cells of other pulmonate molluscs (Nolte, 1983; Griffond and Vincent, 1985; Saleuddin et al., 1989; Buma et al., 1984; Mounzih et al., 1988). The DB of Lymnaea stagnalis does not abundantly express a peptidergic gene, but they express a gene encoding a P450 analogue, which might suggest steroid synthesis (Teunissen et al., 1992). The existence of protein synthesis in these cells need not necessarily be interpreted as evidence for the synthesis of a protein hormone. Steroid hormone-producing gland cells have a high rate of protein synthesis, which is necessary to provide enzymes for steroidogenesis and steroid-binding protein. Proteins could be also involved in 1) intracellular transport of cholesterol or intermediate steroids, as has been described for adrenocortical cells or insect prothoracic glands (Feuilloley and Vaudry, 1996, Birkenbeil, 1983), and 2) in the storage of steroid hormones in secretory granules, as suggested for the DB cells of Helisoma duryi (Saleuddin et al., 1989). On the other hand, the simultaneous synthesis, storage and release of steroids and proteins are considered a general principle for some mammalian steroidogenic cells (Skinner, 1991). Thus, it could reasonably be assumed that the DB gland of $M$. abbreviatus might produce a protein and a steroid secretion, since its cytological features support this possibility.

Another noteworthy aspect of the DB is the existence of vascular structures in the glandular tissue. The great number of small vessels found throughout the DB of Megalobulimus abbreviatus may be considered capillaries. Similar capillaries were observed in the pedal musculature and in the connective sheath that surround the nervous system of M. abbreviatus (Faccioni-Heuser et al., 1999, Nóblega et al., 2006). The fold-like aspect of the endothelial membrane that would contribute to an increased exchange surface reinforces the role of the capillaries in the transport and exchanges with secretory areas such as the DB. The large number of glycogen granules in the cytoplasm of the endothelial cell of the DB from animals fixed in spring time would indicate greater secretory activity of this glandular tissue during the reproductive period.

The presence of a cilium alone in the Megalobulimus abbreviatus DB may be merely a primitive feature that persists in the DB of some pulmonate molluscs, as in Achatina fulica (Takeda and Ohtake, 1994).

The large number of synaptic terminals in relation to a number of DB cells in Megalobulimus abbreviatus indicates that this gland is directly controlled by the central nervous system. There is a consensus as to the type of innervation of the DB cells in the different species of terrestrial pulmonates. Axonal terminals have been identified making synapses en passant between the DB cells (Nolte, 1983; Wijdenes et al., 1983; Wijdenes et al., 1987; Vincent et al., 1984; Griffond and Mounzih, 1990; Ohtake and Takeda, 1994).

In Megalobulimus abbreviatus, the axonal terminals were located in all the analysed regions of the DB, while the small nerves were only found in the dorsomedial region of the $\mathrm{DB}$, posterior to the cerebral commissure. Interestingly, the retrograde labelling obtained from neural tracer injections into the gland tissue revealed that the cerebral neurons of the pleural lobe of the metacerebrum and the parietal ganglia are directly involved 
in this control. The neurons of the metacerebrum could preferentially innervate the supraesophageal portion of the DB, while the parietal neurons could innervate the subesophageal DB cells. Although the innervation of the DB cells has been described for all the analysed stylommatophorans, it has rarely been described for the DB in basommatophoran snails (see reviews: Joosse and Geraerts, 1983; Luchtel et al., 1997). However, DB cells appear to be innervated by cerebral ganglia in Helisoma duryi and Siphonaria pectinata (Saleuddin and Ashton, 1996; Saleuddin et al., 1997), but no synapse-like structures have been found in these animals.

The innervation of the DB in Helix aspersa and Theba pisana originates from peptidergic neurons of the cerebral ganglia (cerebral green cells, CGC) via commissural nerves. This neuronal cluster produces a growth hormone in $H$. aspersa and Agriolimax reticulatus (Wijdenes and Runham, 1976; Wijdenes et al., 1980; Geraerts et al., 1991) and exerts inhibitory control over the DB of H. aspersa (Vincent et al., 1984). These observations reinforce the antagonistic paradigm that exists between growth and reproduction (Wijdenes et al., 1987). The control of the DB secretion(s) may be hormonal (as in most basommatophorans, in which the DB is not innervated), or neurohormonal in locus (as in all stylommatophorans, the limpet Siphonaria pectinata and the basommatophoran Helisoma duryi). No commissural nerves were recognised in Megalobulimus abbreviatus, using classical staining techniques (Zancan and Achaval, 1995). However, at the electron microscopical level, small nerve fascicles were identified in the DB region penetrating the cerebral commissure, as well as positive acetylcholinesterase fibres extending from the cerebral commissure towards the DB (Zancan et al., 1994) and also backfilled axonal processes projecting to DB from the cerebral commissure.

It has been suggested that the neuropeptide FMRFamide might control the secretory activity of the DB cells (Marchand et al., 1991). The axonal terminals within the DB of Megalobulimus abbreviatus were seen to contain material immunoreactive to FMRFamide. In addition, there is a broad network of FMRF-IR axons in close contact with the DB cells of Helix aspersa, both in the supraesophageal and in the subesophageal regions (Marchand et al., 1991). Some electro-dense granules within these axons were FMRFamide-reactive (Griffond and Mounzih, 1990). The CGC peptidergic cells, which, it has been suggested, exert inhibitory control on the DB, are FMRFamide-immunoreactive (Marchand et al., 1991).

On the other hand, in the cerebral ganglia of Helix aspersa and Limax maximus, MIP (molluscan insulinrelated peptide)-related substances were identified in neurons, which are probably the CGC (van Minnen and Schallig, 1990). In other terrestrial snails, such as Helix lucorum and Eobania vermiculata, the identified MIPcontaining neurons were located in the pleural lobe (metacerebrum) and appeared labelled by the DB nerve back- filling (Ierusalimsky and Balaban, 2005). Hence, MIP as well as FMRFamide could exert inhibitory control of reproduction in the terrestrial pulmonate molluscs, as has already been proposed for the basommatophoran snails (Geraerts et al., 1991). Some sequential or simultaneous labelling with neuropeptide-imunoreactive and retrograde marker would clarify the chemical nature of the neurons in cerebral and parietal ganglia that innervate the DB of Megalobulimus abbreviatus.

The cerebral neurons located in metacerebral lobe might be FMRFamide-like neurons and they represent a neural control to the DB in Megalobulimus abbreviatus. This relationship between the central nervous system and a gonadotrophic gland is not unique to the pulmonate gastropods. In the cephalopods (Budelmann et al., 1997), the optic gland, an endocrine gland that has a similar function to the DB, has been considered an analogue of the pituitary gland in the context of reproduction.

Acknowledgements - This study was supported by a grant from the Conselho Nacional de Desenvolvimento Científico e Tecnológico (CNPq) and Fundação de Amparo à Pesquisa do Rio Grande do Sul (FAPERGS). We are indebted to Cristiane Q. Lopes for her assistance with the electron microscopy and to Gabriela Z. Lavina and Malcon A. M. Pereira for their assistance with the illustrations.

\section{References}

BECQUAERT, JC., 1948. Monograph of the family Strophocheilidae, a neotropical family of a terrestrial mollusks. Bulletin: Museum of Comparative Zoology Harvard, vol. 100, no. 1 , p. $1-210$

BIRKENBEIL, H., 1983. Ultrastructural and immunocytochemical investigation of ecdysteroid secretion by the prothoracic gland of the waxmoth Galleria mellonella. Cell and Tissue Research, vol. 229, no. 2, p. 433-441.

BRIDE, J., GOMOT, L. and SALEUDDIN, ASM., 1991. Mating and 20-hydroxyecdysone cause increased galactogen synthesis in the albumen gland explants of Helix aspersa (Mollusca). Comparative Biochemistry and Physiology, vol. 98B, no. 2-3, p. $369-373$.

BUMA,P., ROUBOS,EW. andBUIJS, RM., 1984. Ultrastructural demonstration of exocytosis of neural, neuroendocrine and endocrine secretions with an in vitro tannic acid (TARI-) method. Histochemistry, vol. 80, no. 3, p. 247-256.

BUDELMANN, BU., SCHIPP, R. and BOLETZKY, S., 1997. Cephalopoda. In HARRISON, FW. and KOHN, AJ. (Eds.). The microscopic anatomy of invertebrate. New York: Wiley-Liss. p. $119-414$

COOK, H., 1966. Morphology and histology of the central nervous system of Succinea putris (L.). Archives Neérlandaises de Zoologie, vol. 17, no. 1, p. 1-72.

DAVIS, NT., 1982. Improved methods for cobalt filling and silver intensification of insect motor neurons. Stain Technology, vol. 57, no. 4, p. 239-244.

EBBERINK, RHM., Van LOENHOUT, H., GERAERTS, WPM., HOGENES, TM. and HOOGLAND, H., 1983. Purification and characterization of the ovulation hormone and the dorsal body 
hormone of Lymnaea stagnalis. In LEVER, J. and BOER, HH. (Eds.). Molluscan Neuroendocrinology. Amsterdam: North Holland Publishing. p. 56-58.

EZZUGHAYYAR, A. and WATTEZ, C., 1989. Relatioship between the dorsal bodies activity and the female reproductive activity in the slug Arion rufus (Mollusca Gastropoda Pulmonata). Comptes Rendus de l'Académie des Sciences, vol. 309, no. 11, p. 505-511. (Series 3, Sciences de la Vie)

FACCIONI-HEUSER, MC., ZANCAN, DM., LOPES, C. and ACHAVAL, M., 1999. The pedal muscle of the land snail Megalobulimus oblongus (Gastropoda, Pulmonata): an ultrastructure approach. Acta Zoologica, vol. 80, no. 4, p. 325-357.

FLARI, VA. and EDWARDS, JP., 2003. The role of the endocrine system in the regulation of reproduction in terrestrial pulmonate gastropods. Invertebrate Reproduction and Development, vol. 44 , no. $2-3$, p. $139-161$

FEUILLOLEY, M. and VAUDRY, H., 1996. Role of the cytoskeleton in adrenocortical cells. Endocrine Review, vol. 17, no. 3 , p. 269-288.

GARCIA, M., GRIFFOND, B. and LAFONT, R., 1995. What are the origins of ecdysteroids in gastropods? General and Comparative Endocrinology, vol. 97, no. 1, p. 76-85.

GERAERTS, WPM., SMIT, AB., LI, KW., VREUGDENHIL, E. and Van HEERIKHUIZEN, H., 1991. Neuropeptide gene families that control reproductive behaviour and growth in molluscs. In OSBORNE, NN. (Ed.). Current aspects of the neurosciences. London: Mcmillan Press. p. 255-312.

GRIFFOND, B. and VINCENT, C., 1985. Étude de l'activité des corps dorsaux de l'escargot Helix aspersa Müllerau cours des phases physiologiques de la vie adulte et sous différentes photopériodes. International Journal of Invertebrate Reproduction and Development, vol. 8, no. 1, p. 27-37.

GRIFFOND, B. and MOUNZIH, K., 1990. Innervation of the dorsal body cells of Helix aspersa: immunocytochemical evidence for the presence of FRMFamide-like substances in nerves and synapses. Tissue and Cell, vol. 22, no. 5, p. $741-748$.

HORN, ACM., ACHAVAL, M. and ZANCAN, DM., 2005. The annual reproductive cycle of the snail Megalobulimus abbreviatus Müller, 1774 (Gastropoda, Pulmonata). Revista Brasileira de Biologia = Brazilian Journal of Biology, vol. 65, no. 3, p. 459-467.

IERUSALIMSKY, V. and BALABAN, P., 2005. Morphological basis for coordination of growth and reproduction processes in the CNS of two terrestrial snails. Experimental Brain Research, vol. 161 , no. 4 , p. $465-473$.

JONK-BRINK, M., BERGAMIN-SASSEN, MJM., KUYT, JRM. and TEWARI-KANHAI, AL., 1986. Enzyme cytochemical evidence for the activation of adenilate cyclase in the follicle cells of vitellogenic oocytes by the Dorsal Body Hormone in the snail Lymnaea stagnalis. General and Comparative Endocrinology, vol. 63, no. 2, p. 212-219.

JONG-BRINK, M., SCHALLIG, HDFH., CHARLET, M. and ZONNEVELD, C., 1989. Endocrine interactions between digenetic trematode parasites and their hosts, freshwater snails, with emphasis on the possible role of ecdysteroids. Invertebrate Reproduction and Development, vol. 15, no. 3, p. 201-209.
JOOSSE, J. and GERAERTS, WPM., 1983. Endocrinology. In SALEUDDIN, ASM. and WILBUR, KM. (Eds.). The Mollusca. London: Academic Press. p. 317-406. (vol. 4, Physiology)

KUHLMANN,D., 1966. Derdorsalkorperderstylommatophoren (Gastropoda). Zeitschrift für Wissenschaftliche Zoologie, vol. 173 , no. 3, p. 218-231

KRUSCH, B., SCHOENMAKERS, HJN., VOOGT, PA. and NOLTE, A., 1979. Steroid synthesizing capacity of the dorsal body of Helix pomatia L. (Gastropoda)- an in vitro study. Comparative and Biochemistry Physiology, vol. 64B, no. 1, p. 101-104.

LUCHTEL, DL., MARTIN, AW., DEYRUP-OLSEN, I. and BOER, HH., 1997. Gastropoda: Pulmonata. In HARRISON, FW. and KOHN, AJ. (Eds.). Microscopic anatomy of invertebrates. New York: Willey-Liss. p. 459-718. (vol. 6B, Mollusca II.)

MARCHAND, CD. and DUBOIS, MP., 1986. Immunocytochemical and ultrastructural evidence for supraand subesophageal localization of the dorsal-body cells of snail Helix aspersa. General and Comparative Endocrinology, vol. 63 , no. 3 , p. 374-380.

MARCHAND, CD.; GRIFFOND, B.; MOUNZIH, K. and COLARD, C., 1991. Distribution of methionine-enkephalin-like and FMRFamide-like immunoreactivities in the central nervous system (including dorsal bodies) of snail Helix aspersa Müller. Zoological Science, vol. 8, no. 6, p. 905-913.

MIKSYS, SL. and SALEUDDIN, ASM., 1988. Polysaccharide synthesis stimulating factors from the dorsal bodies and cerebral ganglia of Helisoma duryi (Mollusca: Pulmonata). Canadian Journal of Zoology, vol. 66, no. 2, p. 508-511.

MORIGUCHI-JECKEL, CM., 2001. Imunorreatividade a FRMF-amida no sistema nervoso central e na musculatura pediosa de Megalobulimus oblongus. Rio Grande do Sul: Universidade Federal do Rio Grande do Sul. 90 p. [Dissertação de Mestrado]

MOUNZIH, K., GRIFFOND, B. and ROUBOS, EW., 1988. Investigations of the diurnal activity of the endocrine dorsal bodies in Helix aspersa. Invertebrate Reproduction and Development, vol. 14, no. 2-3, p. 229-244.

MUKAI, ST. and SALEUDDIN, ASM., 1992. Partial characterization of the dorsal body hormone from the snail Helisoma (Mollusca). American Zoologist, vol. 32, no. 5, p. 26A.

MUKAI, ST., STEEL, CGH. and SALEUDDIN, ASM., 2001. Partial characterization of the secretory material from de dorsal bodies in the snail Helisoma duryi (Mollusca: Pulmonata), and its effects on reproduction. Invertebrate Biology, vol. 120, no. 2, p. $149-161$

NÓBLEGA, HG., RIGON, F., STENERT, C., FACCIONI-HEUSER, MC. and ACHAVAL, M., 2006. Permeability of the haemolymph-neural interface in the terrestrial snail Megalobulimus abbreviatus (Gastropoda, Pulmonata): an ultrastructural approach. Comparative Biochemistry and Physiology A, vol. 144, no. 1, p. 119-24.

NOLTE, A., 1983. Investigations on the dorsal bodies of stylommatophoran snails. In LEVER, J. and BOER, HH. (Eds.). Molluscan Neuro-endocrinology. Amsterdam: North-Holland Publishing. p. 142-146.

NOLTE, A., KOOLMAN, J., DORLÖCHTER, M. and STRAUB, H., 1986. Ecdysteroids in the dorsal bodies of 
pulmonates (Gastropoda): synthesis and release of ecdysone. Comparative Biochemistry and Physiology, vol. 84C, no. 2, p. $777-782$.

OHTAKE, S. and TAKEDA, N., 1994. Neuroendocrine control of the dorsal bodies in the giant african snail Achatina fulica. Invertebrate Reproduction and Development, vol. 25, p. 87-92.

SALEUDDIN, ASM., ASHTON, ML. and KHAN, HR., 1989. Mating-induced release of granules by the endocrine dorsal body cells of the snail Helisoma duryi (Mollusca). The Journal of Experimental Zoology, vol. 250, no. 2, p. 206-213.

1997. An electron microscopic study of the dorsal bodies in reproductively active and inactive Siphonaria pectinata (Pulmonata: Mollusca). Tissue and Cell, vol. 29, no. 3 , p. 267-275.

SALEUDDIN, ASM. and ASHTON, ML., 1996. Neuronal pathways of three neurosecretory cells from the lateral lobes in Helisoma (Mollusca): innervation of the dorsal body. Tissue and Cell, vol. 28, no. 1, p. 53-62.

SCHIFF, CJ. and DOSSAGE, SF., 1991. Ecdysteroids as regulators of host and parasite interactions: a study of inter-relationships between Schistosoma mansoni and host snail, Biomphalaria glabrata. Tropical Medicine and Parasitology, vol. 42, no. 1, p. 11-16.

SKINNER, MK., 1991. Cell-cell interaction in the testis. Endocrine Review, vol. 12, no. 1, p. 45-77.

TAKEDA, N. and OHTAKE, SL., 1994. Cilia found in the endocrine dorsal bodies of the giant African snail, Achatina fulica. Journal of Molluscan Studies, vol. 60, no. 3, p. 349-351.

TEUNISSEN, Y., GERAERTS, WPM., Van HEERIKHUISEN, H., PLANTA, RJ. and JOOSSE, J., 1992. Molecular cloning of a member of a novel cytochrome P450 family in the mollusk Lymnaea stagnalis. The Journal of Biochemistry, vol. 112, no. 2, p. 249-252.

THOMÉ, WJ., CARARA, AEQ., MALLMANN, MTO., LOPES, PTC. and SCHNEIDER, VI., 1994. Manual de aulas práticas de zoologia: estudo morfo-anatômico de um molusco gastrópode Mesuretra. Porto Alegre: EDIPUCRS. 32 p.

Van MINNEN, J. and SCHALLIG, HDFH., 1990. Demonstration of insulin-related substances in the central nervous systems of
Pulmonates and Aplysia californica. Cell and Tissue Research, vol. 260 , no. 2 , p. 381-386.

Van MINNEN, J. and SOKOLOVE, PG., 1984. Galactogen synthesis-stimulating factor in the slug, Limax maximus: cellular localization and partial purification. General and Comparative Endocrinology, vol. 54, no. 1, p. 114-122.

VINCENT, C., GRIFFOND, B., WIJDENES, J. and GOMOT, L., 1984. Contrôle d'une glande endocrine: les corps dorsaux par le système nerveux central chez Helix aspersa. Comptes Rendus de l'Académie des Sciences, vol. 299, no. 4, p. 421-426.

WIJDENES, J. and RUNHAM, NW., 1976. Studies on the function of the dorsal bodies of Agriolimax reticulatus (Mollusca: Pulmonata). General and Comparative Endocrinology, vol. 29, no. 4 , p. $545-551$.

WIJDENES, J., SCHLUTER, NCM., GOMOT, L. and BOER, HH., 1987. In the snail Helix aspersa the gonadotropic hormone-producing dorsal bodies are under inhibitory nervous control of putative growth hormone-producing neuroendocrine cells. General and Comparative Endocrinology, vol. 68, no. 2, p. 224-229.

WIJDENES, J., VINCENT, C., GRIFFOND, B. and GOMOT, L., 1983. Ultrastructural evidence for the neuro-endocrine innervation of the dorsal bodies and their probable physiological significance in Helix aspersa. In LEVER J. and BOER, HH. (Eds.). Molluscan Neuro-endocrinology. Amsterdam: North Holland Publishing. p. 147-152.

WIJDENES, J., Van MINNEN, J. and BOER, HH., 1980. A comparative study on neurosecretion demonstrated by Alcian blue - Alcian yellow technique in three terrestrial pulmonates (Stylommatophora). Cell and Tissue Research, vol. 210, no. 1, p. 47-56.

ZANCAN, DM. and ACHAVAL, M., 1995. Morphology of the dorsal body of the pulmonate mollusc Megalobulimus oblongus (Müller, 1774) and its seasonal variations. Revista Brasileira de Biologia $=$ Brazilian Journal of Biology, vol. 55, no. 1, p. 1-11.

ZANCAN, DM., NÓBLEGA, HG., SEVERINO, AG. and ACHAVAL, M., 1994. Acethylcholinesterase distribution in the central nervous system of the Megalobulimus oblongus (Gastropoda, Pulmonata). Archives d'Anatomie d'Histologie et Embryologie Normales et Expérimentales, vol. 75, no. 1, p. $75-86$. 